\title{
Physiological, Photochemical and Antioxidant Responses of Wild and Cultivated Carthamus Species Exposed to Nickel Toxicity and Evaluation of Their Usage Potential in Phytoremediation
}

\section{Uğurcan Baran}

Akdeniz University: Akdeniz Universitesi

Yasemin Ekmekci ( $\square$ yase@hacettepe.edu.tr)

Hacettepe Universitesi Beytepe Kampusu https://orcid.org/0000-0002-1590-9386

\section{Research Article}

Keywords: Carthamus species, safflower, nickel, chlorophyll fluoresence, antioxidant enzymes, accumulation

Posted Date: May 17th, 2021

DOl: https://doi.org/10.21203/rs.3.rs-475470/v1

License: (c) (1) This work is licensed under a Creative Commons Attribution 4.0 International License. Read Full License

Version of Record: A version of this preprint was published at Environmental Science and Pollution Research on August 18th, 2021. See the published version at https://doi.org/10.1007/s11356-021-15493y. 


\section{Abstract}

The responses of growth, photochemical and antioxidant defence of safflower species (Carthamus oxyacantha M. Bieb. and Carthamus tinctorius L. exposed to nickel $(\mathrm{Ni})$ toxicity were investigated in the study. Fourteen-day-old seedlings were treated with excessive Ni levels [control, 0.50, 0.75 and $1.00 \mathrm{mM}$ ] for 7 days. The results of chlorophyll a fluorescence indicated that toxic nickel exposure led to changes in specific, phenomenological energy fluxes and quantum yields in thylakoid membranes, and activities of donor and acceptor sides of photosystems. These changes resulted in a significant decrease in the photosynthetic performance of the species, but these negative effects of Ni were not in a level to destroy the functionality of the photosystems. At the same time, toxic $\mathrm{Ni}$ affected membrane integrity and the amount of photosynthetic pigments in the antenna and active reaction centers. Additionally, the accumulation of $\mathrm{Ni}$ was higher in roots than in stem and leaves for both species. Depending on $\mathrm{Ni}$ accumulation, a significant reduction in dry biomass of root and shoot was observed in both species. Two species could probably withstand deleterious $\mathrm{Ni}$ toxicity with better upregulating own protective defence systems such as antioxidant enzymes. Among of them, SOD and POD activities were increased with increasing Ni concentrations. The POD activities of both species were most prominent and consistently increased in toxic $\mathrm{Ni}$ levels and may be protected them from damaging effect of $\mathrm{H}_{2} \mathrm{O}_{2}$. When all results are evaluated as a whole, Carthamus species produced similar responses to toxicity and also both species have Bioconcentration (BCF) and Bioaccumulation factors (BF) $>1$ and Translocation factor $(\mathrm{TF})<1$ under Ni toxicity may be regarded a good indication of Ni tolerance. Consequently, it is possible to use the Carthamus species in the remediation (phytostabilization) of soils contaminated with nickel, because of their roots accumulating more nickel.

\section{Introduction}

Heavy metal pollution is one of the most worldwide threats to the environment organisms. Nickel is emitted in the environment from a variety of natural (such as serpentine soils) and anthropogenic sources including chemical, food, metallurgical industries (Chen et al., 2009; Sachan and Lal, 2017). Ni is an essential micronutrient for growth and development and some cellular processes of higher plants. Although the concentration of nickel that is required for plant growth is very low, higher Ni concentrations cause toxicity and could lead to several deleterios alterations in plants (Shahzad et al., 2018).

The main way to uptake $\mathrm{Ni}$ from the soil is absorption by the plant roots. Some metals that accumulate in the soil are attached to their organic components and become inaccessible for plants, whereas metal ions can enter the roots easily. $\mathrm{Ni}^{+2}$ uptake and translocation by the plant roots, same as of other metals, take place both passive diffusion and active transport (Seregin and Kozhevnikova, 2006). Nickel uptake and ratio of transport form (active/passive) may vary depending on the species of the plant, oxidation state, $\mathrm{pH}$, concentrations of other metal ions and availability of nickel in the growth medium (Sachan and Lal, 2017; Salinitro et al., 2020). Moreover, Ni, a divalent cation, may compete with other cations with a similar charge/size ratio such as $\mathrm{Fe}, \mathrm{Cu}, \mathrm{Zn}$, and $\mathrm{Mn}$, therefore $\mathrm{Ni}$ toxicity causes the deficiency of these elements (Shahzad et al., 2018; Hassan et al., 2019). 
Most of the deleterious effects of nickel toxicity are associated with the photosynthetic process of the plant via direct and/or indirect ways. Toxic level of Ni indirectly affects stomatal opening though alteration in ion fluxes $\left(\mathrm{K}^{+}\right)$across membranes (Ahmad and Ashraf, 2011). Stomatal limitations allow plants to limit transpiration, but it also limit $\mathrm{CO}_{2}$ absorption, which leads to reduced photosynthetic activity. In addition to that, limitations to $\mathrm{CO}_{2}$ absorption may provoke an imbalance between photochemical activity of photosystems and the electron requirement of the Calvin reactions, leading to an excess of absorbed excitation energy and subsequent photoinhibition (Baker and Rosenqvist, 2004). The action of excess $\mathrm{Ni}$ in photosynthesis may primarily target the reaction center of photosystem II (PSII). The inhibition of electron transport of Ni is mainly on the donor side of PSII and the binding site for $\mathrm{Q}_{B}$, the secondary quinone acceptor of PSII (Mohanty et al., 1989; Bhalerao et al., 2015; Khaliq et al., 2016). Thus, electron transport is restricted in PSII and this restriction leads to nutrient deficiencies in plant as a result of negative affected of assimilation (Hassan et al., 2019). Many photochemical parameters could be calculated from obtained data and provide valuable information about the PSII and PSI functionality. Photosynthetic activity measurements (especially Chl a fluorescence parameters) have been widely used to screen and reveal the effects of metal stress on photosynthetic behaviour of plants (Öz et al., 2014; Sitko et al., 2017; Ekmekçi et al., 2020).

Excessive Ni causes reduction of chlorophyll and carotenoid contents, generation of free radicals, lipid peroxidation, disruption of cell structure, reduction in physiological functions, alteration of many enzymatic activities, destruction of photosynthetic protein complexes and chloroplast structure, dehydration (wilting), and consequently lower biomass production and yield (Sachan and Lal, 2017; Batool, 2018; Amjad et al., 2020). Generation of reactive oxygen species (ROS) enchanced by nickel at elevated levels and this over-production and accumulation of ROS that could not be scavenged may cause damage to several critical bio-molecules like lipids, proteins and nucleic acids in plant tissues (Gajewska and Skłodowska, 2007). Members of defense mechanisms such as enzymatic (SOD, POD, GR, APX, etc.) and non-enzymatic (glutathion, ascorbate, anthocyanin, flavonoid, etc.) antioxidants play an important role in the reducing oxidative damage in plants. Changes in the activity of antioxidant enzymes may vary depending on the plant species as well as nickel concentration (Gajewska and Skłodowska, 2007; Zaid et al., 2019; Amjad et al., 2020).

Carthamus oxyacantha (wild safflower) and Carthamus tinctorius (cultivated safflower) species are an oilseed bioenergy crops which are a member of the family Asteraceae. Safflower is a prominent oilseed crop with its tolerance capacity against such as drought, salt, metal stress etc. (Al Chami et al., 2015; Pourghasemian et al., 2019; Çulha-Erdal et al., 2021). It has also been stated that $C$. tinctorius can be grown on metal-contaminated soils (Al Chami et al., 2015). Production of safflower is not only for food, cosmetic, pharmaceutical and dye industries but also safflower is a substrate for multi-biofuel (ethanol, biogas, and biodiesel) production in a biorefinery approach (Pourghasemian et al., 2019; Hashemi et al., 2020). Moreover, it has been reported that safflower also may be used in phytoremediation (Al Chami et al., 2015; Pourghasemian et al., 2019), but it is poorly known the physiological responses of $C$. oxyacantha and $C$. tinctorius to heavy metal stress, especially nickel. To our knowledge, the effects of 
nickel stress on photosynthetic efficiency by using chlorophyll a fluorescence technique and antioxidant activity of safflower were studied for the first time with present research.

Finally, this study was designed to determine physiological differences, responses and tolerance capacity between two safflower species exposed to increased Ni concentrations using the following approaches:

1) to explore underlying physiological and metabolic mechanisms responsible for Ni toxicity 2) to evaluate the effect of $\mathrm{Ni}$ toxicity on photochemical activity by using polyphasic chlorophyll $a$ fluorescence kinetics, 3 ) to elucidate possible protective role of antioxidant enzyme activity against the Ni induced oxidative stress 4 ) to assess whether or not the potential utilize of Carthamus species as a suitable phytoremediator for Ni-contaminated areas.

\section{Materials And Methods}

\subsection{Plant materials, growth and treatment conditions}

Wild (Carthamus oxyacantha M.Bieb.) and cultivated (Carthamus tinctorius L.) species of safflower used in this study and seeds were provided from Trakya Agricultural Research Institute.

The seeds of safflower were sterilized with $5 \%$ sodium hypochlorite for 5 min. After sterilization, seeds were germinated under dark conditions at $23 \pm 2{ }^{\circ} \mathrm{C}$ for 4 days. Then, seedlings were transferred to hydroponic culture containing Hoagland's nutrient solution and were grown for 10 days in control condition. At the 10th day of the growth, nickel stress was treated by applying Hoagland's nutrient solution containing $0.50,0.75$ and $1.00 \mathrm{mM} \mathrm{NiCl}_{2} \cdot 6 \mathrm{H}_{2} \mathrm{O}$ for next 7 days. The concentration and duration of toxicity groups were decided by preliminary tests on the $1 \mathrm{st}$, 3rd, 5th, 7th, 9th days from the beginning of nickel stress by using polyphasic chlorophyll a fluorescence measurements.

The experiments were carried out in a controlled growth chamber at $25^{\circ} \mathrm{C}, 16$-h light and 8-h dark photoperiod, $180-200 \mu \mathrm{mol} . \mathrm{m}^{-1} \mathrm{~s}^{-1}$ light intensity and $40-50 \%$ humidity. On the $21 \mathrm{st}$ day, plants were harvested and 2nd and 3rd leaves of plants were used for analysis. The dry biomass of roots and shoots of treatment groups were determined as g. plant $^{-1} \mathrm{DW}$.

\subsection{Ni Accumulation}

The plant parts (leaves, stems, roots) were properly rinsed with distilled water and then tissues were ovendried at $80^{\circ} \mathrm{C}$ for $48 \mathrm{~h}$ and ground powder. The powder of tissues $(0.2 \mathrm{~g})$ was ashed in a muffle furnace at $550^{\circ} \mathrm{C}$ for 5 hours. The residue was brought to a standard volume with $1 \mathrm{M} \mathrm{HNO}_{3}$ and then filtered trough whatmann paper. The Ni concentration of the extract was determined by atomic absorption spectrometer (Varian AA2420FS). The Ni concentration [Ni] of tissues [root, shoot (stem + leaf)] was calculated in terms of mg. $\mathrm{kg}^{-1}$ DW. Translocation (TF), Bioconcentration (BCF) and Bioaccumulation Factors (BF) were calculated according to Yoon et al. (2006) and Roccotiello et al. (2010): 
$\mathrm{TF}=\mathrm{BCF}$ of shoot $\left[\mathrm{mg} \cdot \mathrm{kg}^{-1} \mathrm{DW}\right] / \mathrm{BCF}$ of roots $\left[\mathrm{mg} \cdot \mathrm{kg}^{-1} \mathrm{DW}\right]$

$\mathrm{BCF}=[\mathrm{Ni}]$ of root $\left[\mathrm{mg} \cdot \mathrm{kg}^{-1} \mathrm{DW}\right] /[\mathrm{Ni}]$ of the hydroponic solution $\left[\mathrm{mg} \cdot \mathrm{kg}^{-1} \mathrm{DW}\right]$

$\mathrm{BF}=[\mathrm{Ni}]$ of shoot $\left[\mathrm{mg} \cdot \mathrm{kg}^{-1} \mathrm{DW}\right] /[\mathrm{Ni}]$ of the hydroponic solution $\left[\mathrm{mg} \cdot \mathrm{kg}^{-1} \mathrm{DW}\right]$

\subsection{Water status and membran integrity}

The water status of leaves was evaluated by calculating the relative water content (RWC) (Farrant, 2000). Electrolyte leakage was measured according to Redmann et al. (1986) with minor modifications.

\subsection{Polyphasic chlorophyll a fluorescence kinetics measurement}

Chlorophyll a polyphasic fluorescence (OJIP) measurements were performed using the HandyPEA (Hansatech Instruments Ltd., Norfolk, UK) fluorimeter on selected fully expanded 2nd and 3rd leaves. Following a 30 min dark adaptation, samples were illuminated with continuous light $[650 \mathrm{~nm} ; 3.000 \mu \mathrm{mol}$ (photon) $\mathrm{m}^{-2} \mathrm{~s}^{-1}$ for $1 \mathrm{~s}$ ] provided by three LEDs. The fluorescence intensity at $20 \mu \mathrm{s}\left(\mathrm{F}_{0}\right), 100 \mu \mathrm{s}, 300 \mu \mathrm{s}$ $\left(F_{K}\right), 2 \mathrm{~ms}\left(F_{J}\right), 30 \mathrm{~ms}\left(F_{1}\right)$, and maximum fluorescence $\left(F_{M}\right)$ were recorded. The recorded data were analyzed with BiolyzerHP3 to prove the physiological state of the safflower plants. Additionally, the relative variable fluorescence $\left[\mathrm{Vt}\right.$ : between the steps 0 and $\mathrm{K}, \mathrm{V}_{\mathrm{OK}}=\left(\mathrm{F}_{\mathrm{K}}-\mathrm{F}_{0}\right) /\left(\mathrm{F}_{\mathrm{M}}-\mathrm{F}_{0}\right) ; 0$ and $\mathrm{J}, \mathrm{V}_{\mathrm{OJ}}=\left(\mathrm{F}_{J}\right.$ $\left.-F_{0}\right) /\left(F_{M}-F_{0}\right)$; and $I$ and $\left.P, V_{I P}=\left(F_{M}-F_{I}\right) /\left(F_{M}-F_{0}\right)\right]$ (Strasser et al., 2004; Oukarroum et al., 2007) were calculated to elucidated the differences between safflower species in response to nickel toxicity. $V_{K} / V_{J}$ and $\Delta \mathrm{V}_{\mathrm{IP}}$, gives information about the PSII donor side and acceptor side of PSI respectively, were also calculated (Ceppi et al., 2012; Ripoll et al., 2016). Some selected JIP test parameters were used in this study: Maximum quantum yield of primary PSII photochemistry $\left(F_{V} / F_{M}\right)$, specific energy fluxes [the absorption/antenna size (ABS/RC), maximum trapping (TRo/RC), electrons transferred (ETo/RC) and dissipation (Dlo/RC) per active reactive center (RC)], phenomenological energy fluxes [the absorption (ABS/CSo), maximum trapping (TRo/CSo), electron fluxes transferred (ETo/CSo), dissipation (Dlo/CSo) and amount of active PSII RCs (RC/CSo) per leaf cross-section (CS)], performance indexes $\left(\mathrm{PI}_{\mathrm{ABS}}\right.$ and

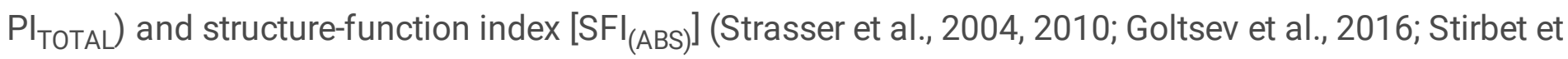
al., 2018). The equations for calculation of JIP-test some parameters are also given in Goltsev et al. (2016).

\subsection{Pigment analysis}

The amount of chlorophyll $(\mathrm{a}+\mathrm{b})$ and carotenoid (xanthophyll $+\beta$-carotene) $\left(\mathrm{mg} \cdot \mathrm{ml}^{-1} \mathrm{~cm}^{-2}\right)$ pigments in leaf tissues of species were determined using method of Lichtenthaler (1987). The anthocyanin content was calculated as described by Mancinelli et al. (1975) and was expressed as $\mathrm{mg} \mathrm{g} \mathrm{FW}^{-1}$ and flavonoid content was measured according to method of Mirecki and Teramura (1984).

\subsection{Hydrogen peroxide $\left(\mathrm{H}_{2} \mathrm{O}_{2}\right)$ content}


The content of $\mathrm{H}_{2} \mathrm{O}_{2}$ of leaves was determined as $\mu \mathrm{mol} \mathrm{g} \mathrm{FW}^{-1}$ according to Esterbauer and Cheeseman (1990).

\subsection{Protein determination and antioxidant enzyme activities}

Fresh leaf samples $(0.5 \mathrm{~g})$ were ground with liquid nitrogen and soluble protein was extracted by homogenizing in related buffer. The protein concentrations of extracts were determined according to Bradford (1976).

Superoxide dismutase (SOD; EC 1.15.1.1) activity was assayed as described by Beyer and Fridovich (1987). One unit of SOD activity was defined as the amount of enzyme required to cause $50 \%$ inhibition of NBT photoreduction. The activity was expressed in units $\mathrm{mg}$ protein ${ }^{-1}$. Ascorbate peroxidase ( APX; EC 1.11.1.11) activity was assayed according to the method of Wang et al. (1991). The enzyme activity was calculated from the initial rate of the reaction using the extinction coefficient of ascorbate $(\mathbb{\nabla}=2.8 \mathrm{mM}$ $\mathrm{cm}^{-1}$ ) at $290 \mathrm{~nm}$. Glutathione reductase (GR; EC 1.6.4.2) activities were determined according to the method of Rao et al. (1995). The enzyme activity was calculated from the initial rate of the reaction after subtracting the nonenzymatic initial oxidation rate using the extinction coefficient of NADPH $(\mathbb{V}=6.2 \mathrm{mM}$ $\mathrm{cm}^{-1}$ ) at $340 \mathrm{~nm}$. Guaiacol peroxidase (POD; EC 1.11.1.7) activity was based on the determination of guaiacol oxidation $\left(\mathbb{Q}=26.6 \mathrm{mM} \mathrm{cm}^{-1}\right.$ ) at $470 \mathrm{~nm}$ by $\mathrm{H}_{2} \mathrm{O}_{2}$ (Bergmeyer, 1974). A unit of peroxidase activity was defined as nmol $\mathrm{H}_{2} \mathrm{O}_{2}$ decomposed per minute per milligram of protein.

\subsection{Statistical analysis}

The experiments were performed in a completely randomized design with 3 replicates. Analysis of variance (ANOVA) of the data was performed using SPSS 20.0 software (IBM SPSS Statistics) and the significance of differences between treatments and spesies was compared using LSD test at $p<0.05$ level.

\section{Results And Discussion}

\subsection{Response of plant growth to excessive Ni toxicity}

Nickel has an adverse effect on plant growth and development at toxic levels. Increasing nickel accumulation of plants leads to alterations in physiological, biochemical and metabolic processes that causes a reduction in growth and biomass production. While low concentrations of Ni play important role in plant growth and development (Chen et al., 2009), high concentrations of Ni reduce shoot and root lenght and dry biomass production in crops (Seregin et al., 2003; Schaaf et al., 2006; Ahmad and Asraf, 2012). A primary phenotypic effect of Ni toxicity induced generally growth inhibition in both safflower species (Fig. 1A-D). The reduction in the root and shoot dry biomass of both species was determined in all Ni treatments compared to the their controls (Fig. 1A and B). It was noticed that the most common response of plants to nickel toxicity was growth inhibition depending on reduction dry matter yield (Khaliq 
et al., 2016; Batool, 2018). Also, the reduction in the shoot dry biomass of $C$. oxyacantha was more drastic than that of $C$. tinctorius. In addition to that, the roots of both species have exhibited blackening and stunted growth behaviour, in concordance with the results of study on C. tinctorius of Al Chami et al. (2015). The stunted growth symptom of Ni toxicity inhibits root elongation and growth to a greater extent than shoot growth (Seregin and Kozhevnikova, 2006). Furthermore, it was observed that a lateral root development was reduced depending on increased nickel concentration for both species. It has been stated that the inhibition of lateral root formation is a characteristic of Ni toxicity compared to other heavy metals and this response has been explained by the accumulation of nickel in the pericyclic cells (Seregin et al., 2003). Previous studies have showed an excess Ni concentrations causes metabolic toxicity that alters the function of root system, thereby inhibiting the uptake of essensial nutrients and mitotic activity of root meristem (Seregin and Kozhevnikova, 2006; Bhalerao et al., 2015; Rizwan et al., 2017). Schaaf et al. (2006) have observed that toxic Ni levels did not affect mitotic activity in root meristem, conversely limits longitudinal root cell expansion and also promotes radial cell expansion. Lescova et al. (2020) and Merlot (2020) have suggested that increase in ROS in the root cells exposed the highly toxic Ni regulates the activities of PIN2 transporters, so affecting the auxin homeostasis and subsequent root growth. However, the mechanism of adverse effect of $\mathrm{Ni}$ on plant growth has not been adequately clarified.

Ammen et al. (2019) stated that one of the possible reasons of the reduction in dry biomass is the loss of water content under toxic $\mathrm{Ni}$ levels. Heavy metals like $\mathrm{Ni}$ considerably reduce the movement of water from roots to upper parts of plant, thereby leading to shoot dehydration (Chen et al., 2004). Excessive Ni levels induced wilting due to gradually reduced RWC of leaves in safflower species (Fig. 1E). Many researchers reported that high amount of $\mathrm{Ni}$ accumulation in plants caused a reduction in water content and transpiraton rate of the leaves (Pandey and Sharma, 2002; Seregin and Koznevnikova, 2006; Gajewska et al., 2006; Chen et al., 2009; Hassan et al., 2019). At the highly toxic Ni concentration (1.00 mM), the RWC for $C$. oxyacantha was decreased by $56.3 \%$, while for $C$. tinctorius $43.0 \%$ compared to controls. The reason of decrease in leaf RWC of both species grown under excessive Ni levels could be disruption of water uptake from roots due to the higher negative osmotic potential of hydroponic medium. Severe dehydration in safflower leaves could be due to an increase in electrolyte leakage in the leaves exposed to $\mathrm{Ni}$ toxicty (Fig. 1F). The membrane is the first part of the cell that comes in contact with toxic metals that destroy membrane integrity and fluidity (Hassan et al., 2019). RLR of $C$. oxyacantha leaves was increased with increasing Ni concentrations by 2.40, 2.67 and 4.67 folds, while for $C$. tinctorius 2.07, 2.99 and 5.27 folds, respectively. Based on the electrolyte leakage results, a greater extent of membrane damage was observed at the highly toxic Ni level in both species.

\subsection{Nickel accumulation and tolerance to Ni toxicity}

Nickel accumulation in roots, stems and leaves are shown in Table 1. Carthamus species accumulated Ni in descending order of root > stem > leaf. Under all toxic treatments, Ni contents in root and shoot tissues of both species progressively increased in a concentration-dependent manner. These results demonstrated that large amounts of nickel were accumulated primarly in the roots than the other part of 
plant, while a small amount of nickel gradually translocated to the above-ground organs for safflower species. Many studies on the other plant species have also reported that greater amount of nickel accumulates in the roots (Al Chami et al., 2015; Gonzales et al., 2015; Syam et al., 2016; Rizwan et al., 2017; Parlak, 2020). Differences between nickel accumulation in the root and stem of both genotypes were determined significant in toxic Ni concentrations, except $0.50 \mathrm{mM}$, whereas it is not significant in leaves. The highest $\mathrm{Ni}$ accumulation was determined at the $1.00 \mathrm{mM}$ Ni treatment in the roots of $C$. oxyacantha and $C$. tinctorius by 4662 and $3385 \mathrm{mg} \mathrm{kg}^{-1}$ DW respectively. However, $C$. oxyacantha transferred generally less amounts of nickel to stem and leaves compared to $C$. tinctorius. BCF, BF and TF factors for species under toxic Ni conditions are calculated and given in Table 1. TF values of both species were determined below one (TF $<1)$. The low TF (less than 1) for Ni might indicate that both species stored nickel in the roots, so roots were the primary regulation parts and then were translocated less amount of $\mathrm{Ni}$ to shoot. The translocation of the essensial metals as $\mathrm{Ni}$ from roots to leaves was lower compared to non essensial metals (Takarina and Pin, 2020). The BCF is a important value to reflect the capacity of plant to accumulate heavy metals from the soil (Wang et al., 2018). BCF and BF values (> 1) represents the ability of plants to accumulation of $\mathrm{Ni}$ in the roots and shoots, respectively (Netty et al., 2013). In present study, BCF values of both species were higher than 1. Yoon et al. (2006) and Roccotiello et al. (2010) have stated that plants can be defined phytostabilizers if they possess BCF and BF $>1$ and $\mathrm{TF}<1$ values. These results have shown that safflower species are Ni tolerant plant and they can be used for the phytostabilisation of Ni contaminated soils.

\subsection{Photochemical response to Ni toxicity}

Many abiotic stress such as metal toxicity directly or indirectly affect the photosynthetic activity of plants and as a consequence alter the chlophyll a fluorescence kinetics (Sitko et al., 2017). Nickel toxicity also inhibits photosynthesis (Velikova et al., 2011), but its effects on photochemical activity are still not fully understand. The polyphasic chlorophyll a fluoresence transients (OJIP), provides detailed information about photosynthetic fluxes analyses using JIP test, can be used as a tool to answer the question about stress induced alterations in plant (Oukarroum et al., 2007; Kalaji et al., 2016). Typical shape of OJIP transient curves has three main phases including $0-\mathrm{J}, \mathrm{J}-\mathrm{I}$ and I-P represents the changes in the redox state of photosystems and very sensitive to environmental stresses (Strasser et al., 2004; Umar et al., 2009). Both safflower species exposed to toxic nickel treatments differed obviously regarding the shape of the OJIP fluoresence transient curves and changes of amplitude from those of their controls (Fig. 2A and B). Highly toxic Ni level induced marked increase in $0-J$ fluoresence rise of $C$. tinctorious at compared to other treatments. $O$ to $\mathrm{J}$ rise which is a photochemical phase, represents $Q_{A}$ reduction to $Q_{A}{ }^{-}$in $P S I I$ and also gives information about an antenna size (Kalaji et al., 2016; Küpper et al., 2019). Toxic Ni concentration caused largest increases in $\mathrm{J}$ step in $C$. tinctorius. Increase in $\mathrm{J}$ step and also I step reflects the start of $Q_{A}$ re-oxidation by $Q_{B}$ and $P Q$ (Strasser et al., 1995), so an increase in J step would suggest a problem in $Q_{A}$ re-oxidation and build up reduced $Q_{A}$. Meanwhile, the increased value of $V_{J}$ and $V_{1}$ of species at nickel toxicity confirmed the accumulation of reduced $Q_{A}$ and $P Q$ which was blocked further electron transport. The J-I and I-P rise represent non-photochemical phases (Strasser et al., 1995). Most 
pronounced decrease in I step was determined in C.oxyacantha at highly toxic Ni level. The decline in the I-P amplitute of polyphasic rise in both species was found to be significant in toxic Ni treatments compared to their controls but this effect was most remarkable $C$. oxyacantha especially $1.00 \mathrm{mM} \mathrm{Ni}$ concentration. The decline in the I-P phase reflects the reduction of the acceptor side of PSI (Kalaji et al., 2016). The amplitute of the relative variable fluoresence of the I to $P$ rise $\left(\Delta V_{I P}\right)$ decreased in both species under toxic Ni conditions (bottom insert in Fig. $2 \mathrm{~A}$ and $\mathrm{B}$ ). $\Delta \mathrm{V}_{\mathrm{IP}}$ is a an important parameter to measure the ratio of PSII/PSI and can be used as an indicator for changes in PSI content (Ceppi et al., 2012; Umar et al., 2019). These results showed that Ni toxicity decreased PSI content of safflower species, the lower values of $\Delta V_{I P}$ expressed a smaller pool of electron acceptor in PSI. Meanwhile, increased in $V_{K} / V_{J}$ indicated that Ni toxicity significantly affected donor side of PSII in species (upper insert in Fig. 2A and $B)$, which may imply to possible damage and inactivation of the oxygen evolving complex (OEC). This response were supported by the changes in $V_{O K}$ and $V_{O J}$, which also indicate either limitation of the OEC or/and an increase of PSII antenne size of both species.

The JIP test is based on the theory of energy fluxes across thylakoid membranes (Strasser et al., 2000). JIP parameters representing the energy fluxes are divided into specific and phenomenological. Specific energy fluxes parameters ( $A B S / R C, T R_{0} / R C, E T_{0} / R C, R E_{0} / R C$ ) calculated per reaction center $(R C)$ of both species were affected from toxic Ni treatments (Fig. $3 A$ and $B$ ). The flux of absorption and trapping per reaction center of PSII, defined as $A B S / R C$ and $T R_{0} / R C$ respectively, were significantly increased in both species at only highly toxic $(1.00 \mathrm{mM}) \mathrm{Ni}$ treatment. Increase in $A B S / R C$ value means that, either fraction of reaction centers is inactivated or the apparent antenna size increased (Ceurters et al., 2019). The increase of $A B S / R C$ was accompanied by increase of trapping per reaction centers $\left(T R_{0} / R C\right)$ in both species at $1.00 \mathrm{mM}$ Ni treatment. It has been suggested that the accumulation of inactive reaction centers is associated with the increased efficiency of dissipation of absorbed light as heat. The higher values of dissipation energy flux per reaction center $\left(\mathrm{DI}_{0} / \mathrm{RC}\right)$ of both species indicated that the energy dissipation ( $\varphi_{\mathrm{D} 0}$ and $\mathrm{DI}_{0} / \mathrm{RC}$ ) is enhanced in order to protect plants exposed to stress from over-excitation and photo-oxidative damage, so excess absorbed light energy was converted to heat dissipation. The value of $\varphi_{D 0}$ (the quantum yield at $t=0 ; F_{0} / F_{M}$ ) of both species was increased significantly with increasing $\mathrm{Ni}$ concentrations $(0.75$ and $1.00 \mathrm{mM})$. Also the reduction in the $\mathrm{TR}_{0} / \mathrm{RC}$ at $\mathrm{Ni}$ treatments (except $1.00 \mathrm{mM}$ ) resulted in reduced electron transport per reaction center $\left(E T_{0} / R C\right)$ as well as $R E_{0} / R C$ due to lower amount of trapped energy. The electron transport from $Q_{A}{ }^{-}$to $P S I$ electron aceptor $\left(R E_{0} / R C\right)$ in both species decreased in all treatments compared to their controls, but it increased in $C$. tinctorius in only higly toxic Ni level compared to other treatments. At the $1.00 \mathrm{mM} \mathrm{Ni}$ induced a significant decrease in the maximum PSIl quantum yield $\left(F_{V} / F_{M}\right)$ of both species compared with their controls. The decline in the $F_{V} / F_{M}$ value was connected with reduced effectiveness of $E T_{0} / R C$, increased of dissipated energy and disruption of antenna complex of PSII (Kalaji et al., 2012; Umar et al., 2019). SFI (ABS), a structure and functioning indicator of PSII, was significantly decreased depending on increasing in Ni levels (especially more toxic than $0.50 \mathrm{mM}$ ) (Fig. $3 \mathrm{~A}$ and B). This pointed out that Ni caused damage in photosynthetic process. Stirbet et al. (2018) have suggested that decrease in $\mathrm{SFI}_{(\mathrm{ABS})}$ and increase in energy dissipation 
might be due to the increase in inactive reaction centers and decrease in quantum yield of photochemistry. Ni toxicity adversely affected the photosynthetic performance indexes $\left(\mathrm{PI}_{\mathrm{ABS}}\right.$ and $\mathrm{PI}_{\text {TOTAL }}$ ) and their companents. Decrease in PI's in stress treatments suggested decrease in overall photosynthetic performance associated with generally decrease of electron transport capacity (Oukarroum et al., 2007).

The phenomenological parameters are calculated per sample cross section (CS) and can be plotted as energy pipeline leaf model (Kalaji et al., 2016). The model demostrated the proportion of active and inactive PSII reaction centers per cross-section (Fig. 4). Related parameters such as efficiency of light absorption $\left(\mathrm{ABS} / \mathrm{CS}_{0}\right)$, trapping $\left(\mathrm{TR}_{0} / \mathrm{CS}_{0}\right)$ and electron transport $\left(\mathrm{ET}_{0} / \mathrm{CS}_{0}\right)$ decreased at toxic nickel levels while dissipation per cross section of PSII $\left(\mathrm{DI}_{0} / \mathrm{CS}_{0}\right)$ increased in response to nickel toxicity. Nickel toxicity caused increasing in inactive reaction centers and producing dissipative sinks for excitation energy, and resulting in decrease in $\mathrm{ET}_{0} / \mathrm{CS}_{0}$. These changes were somewhat more in C.oxyacanthathan in C. tinctorius.

JIP test analyses showed that, the decrease of photochemical efficiency related to increase in dissipation and reduced of active reaction centers were found in both species affected highly toxic Ni treatments. It was determined that the Ni toxicity were affected more acceptor side of PSI and its components than donor side of PSII. But these adversely effects of $\mathrm{Ni}$ on photosystems were not in a level to cessation the functionality of them. This was consistent with the electrolyte leakage results (Fig. 1F).

\subsection{Effect of Ni toxicity on pigment contents}

Nickel toxicity leads to leaf chlorosis and necrosis (Singh and Pandey, 2010; Hassan et al., 2019). The decrease in total chlorophyll and carotenoid content of both species leaves at toxic Ni levels resulted in an inhibition on photochemical activity (Table 2 and Fig. 3). The leaves of both safflower were significantly affected by Ni treatments, which resulted in the devastation of chlorophyll including chlorosis and necrosis. The chlorophyll pigments of both genotypes leaves remarkably declined (about 40-60\%) with increasing Ni concentrations compared with controls. Consequently, these changes were reflected to chlorophyll a/b ratio and the ratio was decreased with increasing toxicity (Table 2 ). Çiçek and Çakırlar (2008) have suggested that this ratio indicates the antenna size of photosystems. The core antenna contain only chl-a, whereas the outher antenna contains both chlorophlls. So, a smaller chl a/b ratio points out larger antenna size, higher ratio smaller antenna size. This finding is consistent with $\mathrm{ABS} / \mathrm{RC}$ results (Fig. 3). In addition to that, decrease in the chlorophyll pigment under excessive $\mathrm{Ni}$ conditions are generally proposed to be increased oxidative stress and competition with essential microelements, including iron (Seregin and Kozhevnikova, 2006; Leskova et al., 2017). It could be suggested that the high concentration of $\mathrm{Ni}$ competed with iron in root cell then it prevent uptake of iron and induced the appearance of chlorosis symptoms that resembling iron deficiency. Chlorophyll pigments perform most of the light harvesting operations, while carotenoids provide protection against excessive light energy as well as light harvesting (Yao and Liu, 2007; Ekmekci et al., 2008). It was showed that carotenoid content was significantly declined in Ni treatments for both species. 
Anthocyanin belong to the flavonoid group of polyphenolic compounds, which are water-soluble nonphotosynthetic pigments in plants. Anthocyanin and flavonoid act as antioxidants and protect the photosynthetic apparatus from damage due to high energy fluxes as an optical filter (Baskar et al., 2018; Stetsenko et al., 2020). Anthocyanin content of the safflower species increased under Ni stress. The anthocyanin content of $C$. oxyacantha at $1.00 \mathrm{mM} \mathrm{Ni}$ level was approx. fifteen folds higher than that of the control. In contrast to wild species, anthocyanin content of $C$. tinctorius was around six folds higher than that of the control (Fig. 5A). Our results are coherence with the results of previously carried out studies (Singh et al., 2011; Rizwan et al., 2017). Flavonoids can also enhance plant defence against heavy metal stress by chelating transition metal ions which trigger the ROS production (Khalid et al., 2019). Flavonoid content of both species increased with increasing Ni levels (Fig. 5B). This increase was nine times higher at highly toxic level in $C$. oxyacantha, while the four times higher in $C$. tinctorius compared with their controls. However, it was clear that flavonoid content of wild type in all Ni levels was higher than that of cultivated type. Kovácik et al. (2009) also reported that the increased concentration of flavonoids was found in the leaves under high $\mathrm{Ni}^{2+}$. Increased of anthocyanins and flavonoids could be correlated with $\mathrm{Ni}$ induced ROS generation which evidence through enhanced membrane leakage and $\mathrm{H}_{2} \mathrm{O}_{2}$ generation (Fig. $1 \mathrm{~F}$ and Fig. $5 \mathrm{C}$ ).

\subsection{Response of antioxidant enzyme activities to Ni toxicity}

$\mathrm{Ni}$ is a redox inactive metal which could indirectly initiate oxidative stress by disrupting the balance of formation and destruction of ROS associated with normal cellular metabolism (Chen et al., 2009). The accumulation of ROS in plants damages cell membrane, lipids, pigments, enzymes, chloroplasts, and nucleic acids etc. (Hassan et al., 2019). The antioxidant defence system plays an important role in scavenging harmful ROS in order to protect plant cell from oxidative damage (Ameen et al., 2019). Carthamus species were exposed to toxic Ni levels which could potentially increase the probability of generating ROS due to excess excitation, resulting in possible damage and/or deterioration of membrane integrity (Fig. 1F and Fig. 2). To cope with ROS plant cells possess an antioxidative system consisting of both enzymatic and non-enzymatic antioxidants. In this study, some antioxidant enzymes exhibited different responses to excess Ni (Fig. 6).

SOD is considered to be the first step of defense against ROS (Gajewska and Skłodowska, 2007). The activity of SOD increased with elevated Ni levels in leaves and roots of both species (Fig. 6A and B). These increases were by 10.2 and 8 folds in roots of $C$. tinctorius and $C$. oxyacantha at a highly toxic Ni levels compared to their controls, respectively. In contrast, the activity of SOD increased by 5.7 and 11.2 folds in leaves of $C$. tinctorius and $C$. oxyacantha at $1.00 \mathrm{mM}$ Ni levels, respectively. Many studies have confirmed that nickel toxicity causes increase in SOD activity of various plants (Ali et al., 2003; Gajewska and Sklodowska, 2006; 2007). As a result of the reaction catalyzed by the SOD, hydrogen peroxide $\left(\mathrm{H}_{2} \mathrm{O}_{2}\right)$ is produced. The amounts of $\mathrm{H}_{2} \mathrm{O}_{2}$ were significantly increased in all nickel concentrations in leaves of $C$. tinctorius, while changes of the $\mathrm{H}_{2} \mathrm{O}_{2}$ amounts in those of $C$. oxyacantha were significant only at $0.50 \mathrm{Ni}$ treatment compared to controls (Fig. 5C). The $\mathrm{H}_{2} \mathrm{O}_{2}$ are scavenged by APX catalyzes a reduction of $\mathrm{H}_{2} \mathrm{O}_{2}$ using ascorbate as an electron donor. It was found that there were no significant changes in the activities 
of APX in the root of both species, but the activity in the leaves increased for both species in all Ni levels when compared to their controls (Fig. 6C and D). Previous studies have shown that APX enzyme activity increases (Kumar and Sharma, 2012) or does not change (Gajewska and Sklodowska, 2007) under nickel stress. There were also no significant changes in the GR activity of roots in both species; however, $C$. oxyacantha showed significantly higher GR activity in leaves, while an insignificant change in GR activity was observed in $C$. tinctorius compared to their controls (Fig. 6E and F). It has been reported in other studies that GR activities in both organs were increased under Ni toxicity (Kumar et al., 2012; Abdelgawad et al., 2020). The activities of GR and APX, enzymes taking part in the Asada-Halliwell cycle, were determined remarkably little responsible for $\mathrm{H}_{2} \mathrm{O}_{2}$ detoxcification in both species exposed to $\mathrm{Ni}$ treatments (Fig. $6 \mathrm{C}-\mathrm{F}$ ). On the other hand, POD is also capable of scavenging $\mathrm{H}_{2} \mathrm{O}_{2}$. These enzymes constitute second step of defense against the ROS production (Ahmad and Ashraf, 2012). Excessive Ni levels were increased POD activities in the roots for $C$. oxyacantha and $C$. tinctorius (Fig. $6 \mathrm{G}$ and H). The highest increase in POD activity was determined at higly toxic Ni concentration (1.00 mM) in the roots of both species. These increases were by 1.9 and 2.2 folds in the roots of $C$. tinctorius and $C$. oxyacantha at a highly toxic Ni levels compared to their controls, respectively. Our results showed that Ni-induced POD activity increased in root and leaf tissues of both species, and this increase was much more in the their roots. The removal of harmfull concentration of $\mathrm{H}_{2} \mathrm{O}_{2}$ was probably achieved by POD enzymes. The POD activity of both species was most prominent and consistently increased in excessive Ni levels and may be protected from oxidative damage. Also many researchers have stated that, POD, which are stress enzymes in plants, were used a potential biomarker for metal toxicity in plants (Radotic el al., 2000; Ekmekçi et al., 2008; Wang et al., 2010; Nadgorska-Socha et al., 2013).

\section{Conclusion}

The results of study demonstrated that large amounts of $\mathrm{Ni}$ were accumulated in the roots more than upper parts of safflower species when exposed to Ni toxicity. The excessive Ni levels caused the limitation of growth and water uptake, loss of chlorophyll, accompany by reduce in photochemical activity. The decline in photochemical performance of species under elevated Ni concentrations might correlated with increasing in inactive reaction centers and decreasing in electron transport capacity. Down-regulation of photosynthetic efficiency together with a significant increase in energy dissipation could play a vital role in protecting both species suffered from Ni toxicity from pressure of over-excitation energy and photoinhibition. Additionally, Carthamus species may have cope with Ni toxicity by upregulating antioxidant defence capacity as well as increasing anthocyanin and flavonoid contents and especially POD activities may protect species from oxidative damage. It was not possible to distinguish two species from each other in terms of their similar responses to toxicity. Concequently, Carthamus species that exhibited better tolerance response to $\mathrm{Ni}$ toxicity can be considered as potential $\mathrm{Ni}$ phytostabilizator contaminated areas.

\section{Declarations}




\section{Acknowledgements}

Authors are thankful to Prof. Dr. Nuran Çiçek, University of Hacettepe for scientific redaction and suggestion of the manuscript. This study was submitted to the Graduate School of Science and Engineering at the Hacettepe University as a MSc thesis of Uğurcan Baran (2018YL59102).

\section{Author's contributions}

Uğurcan Baran performed all the experiments and drafted the manuscript. Yasemin Ekmekçi supervised the overall work and provided critical comments, and reviewed and edited the manuscript.

\section{Ethical Approval and Consent for Participate Not applicable}

Consent for Publish Not applicable

Availability of data and materials All data generated or analysed in the study are included in this manuscript.

Competing Interests The authors declare that they have no known competing financial interests or personal relationships that could have appeared to influence the work reported in this paper.

\section{References}

1. Abdelgawad H, Zinta G, Hamed BA et al (2020) Maize roots and shoots show distinct profiles of oxidative stress and antioxidant defense under heavy metal toxicity. Environ. Pollut. 258:113705. https://doi.org/10.1016/j.envpol.2019.113705

2. Ahmad MSA, Ashraf M (2012) Essential roles and hazardous effects of nickel in plants, In: Whitacre D. (ed). Rev. Environ. Contam. T., Springer, New York, pp 125-167. https://doi.org/10.1007/978-14614-0668-6_6

3. Al Chami Z, Amer N, al Bitar L, Cavoski I (2015) Potential use of Sorghum bicolor and Carthamus tinctorius in phytoremediation of nickel, lead and zinc. Int. J. Environ. Sci.Technol. 12:3957-3970. https://doi.org/10.1007/s13762-015-0823-0

4. Ali MB, Vajpayee P, Tripathi RD, Rai UN, Singh SN, Singh SP (2003) Phytoremediation of lead, nickel, and copper by Salix acmophylla Boiss.: Role of antioxidant enzymes and antioxidant substances. Bull. Environ. Contam. Toxicol. 70:462-469. https://doi.org/10.1007/s00128-003-0009-1

5. Ameen N, Amjad M, Murtaza B, Abbas G, Shahid M, Imran M, Naeem MA, Niazi NK (2019) Biogeochemical behavior of nickel under different abiotic stresses: toxicity and detoxification mechanisms in plants. Environ. Sci. Pollut. Res. 26:10496-10514. https://doi.org/10.1007/s11356019-04540-4

6. Amjad M, Raza H, Murtaza B et al 2020. Nickel toxicity induced changes in nutrient dynamics and antioxidant profiling in two maize (Zea mays L.) hybrids. Plants. 9:1-16. https://doi.org/10.3390/plants9010005 
7. Baker NR, Rosenqvist E (2004) Applications of chlorophyll fluorescence can improve crop production strategies: An examination of future possibilities. J. Exp. Bot. 55:1607-1621. https://doi.org/10.1093/jxb/erh196

8. Baskar V, Venkatesh R, Ramalingam S (2018) Flavonoids (antioxidants systems) in higher plants and their response to stresses, in: Gupta D., Palma J., Corpas F. (ed). Antioxidants and Antioxidant Enzymes in Higher Plants, Springer, Cham, pp 253-268. https://doi.org/10.1007/978-3-319-750880_12

9. Batool S, (2018) Impact of bioaccumulation of nickel on growth, seed yield and mineral uptake of chickpea (Cicer arietinum L.) varieties. Pak. J. Bot. 50:2147-2150.

10. Bergmeyer HU, Bernt E (1974) Glutamate-oxaloacetate transaminase. Methods of Enzymatic Analysis. 2:727-733.

11. Beyer WF, Fridovich I (1987) Assaying for superoxide dismutase activity: some large consequences of minor changes in conditions. Anal. Biochem. 161:559-566.

12. Bhalerao SA, Sharma AS, Poojari AC (2015) Toxicity of nickel in plants. Int. J. Pure Appl. Biosci. 3:345-355.

13. Bradford MM (1976) A rapid and sensitive method for the quantitation of microgram quantities of protein utilizing the principle of protein-dye binding. Anal. Biochem. 72:248-254.

14. Ceppi MG, Oukarroum A, Çiçek N, Strasser RJ, Schansker G (2012) The IP amplitude of the fluorescence rise OJIP is sensitive to changes in the photosystem I content of leaves: a study on plants exposed to magnesium and sulfate deficiencies, drought stress and salt stress. Physiol. Plant. 144:277-288. https://doi.org/10.1111/j.1399-3054.2011.01549.x

15. Ceusters N, Valcke R, Frans M, Claes JE, van den Ende W, Ceusters J (2019) Performance index and PSII connectivity under drought and contrasting light regimes in the CAM orchid phalaenopsis. Front. Plant Sci. 10:1-15. https://doi.org/10.3389/fpls.2019.01012

16. Chen Y, Li X, Shen Z (2004) Leaching and uptake of heavy metals by ten different species of plants during an EDTA assisted phytoextraction process. Chemosphere. 57:187-196.

17. Chen C, Huang D, Liu J (2009) Functions and toxicity of nickel in plants: Recent advances and future prospects. Clean Soil, Air, Water 37:304-313. https://doi.org/10.1002/clen.200800199

18. Çiçek N, Çakirlar H (2008) Effects of salt stress on some physiological and photosynthetic parameters at three different temperatures in six soya bean (Glycine max L. Merr.) cultivars. J. Agron. Crop Sci. 194:34-46. https://doi.org/10.1111/j.1439-037X.2007.00288.x

19. Çulha Erdal Ş, Eyidoğan F, Ekmekci Y (2021) Comparative physiological and proteomic analyses of cultivated and wild safflower response to drought stress and rewatering. Physiol. Mol. Biol. Plants. 27:281-295. https://doi.org/10.1007/s12298- 021-00934-2

20. Ekmekçi Y, Tanyolaç D, Ayhan B (2008) Effects of cadmium on antioxidant enzyme and photosynthetic activities in leaves of two maize cultivars. J. Plant Physiol. 165:600-611. https://doi.org/10.1016/j.jplph.2007.01.017 
21. Ekmekçi Y, Çulha Erdal Ş, Balkan Nalçaiyi AS, Çiçek N (2020) The acquisition of boron tolerance by salt pretreatment in two sunflower cultivars. Turk. J. Bot. 44:153-166. https://doi:10.3906/bot-191026.

22. Esterbauer H, Cheeseman KH (1990) Determination of aldehydic lipid peroxidation products: Malonaldehyde and 4-hydroxynonenal. Method. Enzymol. 186:407-421.

23. Farrant JM (2000) A comparison of mechanisms of desiccation tolerance among three angiosperm resurrection plant species. Plant Ecol. 151:29-39. https://doi.org/10.1023/A:1026534305831

24. Gajewska E, Skłodowska M (2007) Effect of nickel on ROS content and antioxidative enzyme activities in wheat leaves. BioMetals. 20:27-36. https://doi.org/10.1007/s10534-006-9011-5

25. Gajewska E, Skłodowska M, Słaba M, Mazur J (2006) Effect of nickel on antioxidative enzyme activities, proline and chlorophyll contents in wheat shoots. Biol. Plant. 50:653-659. https://doi.org/10.1007/s10535-006-0102-5

26. Goltsev VN, Kalaji HM, Paunov M, et al (2016) Variable chlorophyll fluorescence and its use for assessing physiological condition of plant photosynthetic apparatus. Russ. J. Plant Physiol. 63:869-893. https://doi.org/10.1134/S1021443716050058

27. Gonzalez Cl, Maine MA, Cazenave J, Hadad HR, Benavides MP (2015) Ni accumulation and its effects on physiological and biochemical parameters of Eichhornia crassipes. Environ. Exp. Bot. 117:20-27. https://doi.org/10.1016/j.envexpbot.2015.04.006

28. Hashemi SS, Mirmohamadsadeghi S, Karimi K (2020) Biorefinery development based on whole safflower plant. Renew. Energ. 152:399-408. https://doi.org/10.1016/j.renene.2020.01.049

29. Hassan MU, Chattha MU, Khan I et al (2019) Nickel toxicity in plants: Reasons, toxic effects, tolerance mechanisms, and remediation possibilities-a review. Environ. Sci. Pollut. Res. 26:1267312688. https://doi.org/10.1007/s11356-019-04892-x

30. Kalaji HM, Carpentier R, Allakhverdiev SI, Bosa K (2012) Fluorescence parameters as early indicators of light stress in barley. J. Photoch. Photobio. B. 112:1-6.

https://doi.org/10.1016/j.jphotobiol.2012.03.009

31. Kalaji HM, Jajoo A, Oukarroum A et al (2016) Chlorophyll a fluorescence as a tool to monitor physiological status of plants under abiotic stress conditions. Acta Physiol. Plant. 38:1-11. https://doi.org/10.1007/s11738-016-2113-y

32. Khaliq A, Ali S, Hameed A et al (2016) Silicon alleviates nickel toxicity in cotton seedlings through enhancing growth, photosynthesis, and suppressing Ni uptake and oxidative stress. Arch. Agron. Soil Sci. 62:633-647. https://doi.org/10.1080/03650340.2015.1073263

33. Khalid M, Saeed-ur-Rahman Bilal M, Huang D (2019) Role of flavonoids in plant interactions with the environment and against human pathogens - A review. J Integr. Agric. 18:211-230. https://doi.org/10.1016/S2095-3119(19)62555-4

34. Kováčik J, Klejdus B, Bačkor M, (2009) Phenolic metabolism of Matricaria chamomilla plants exposed to nickel. J. Plant Physiol. 166:1460-1464. https://doi.org/10.1016/j.jplph.2009.03.002 
35. Kumar H, Sharma D, Kumar V (2012) Nickel-induced oxidative stress and role of antioxidant defence in barley roots and leaves. Int. J. Environ. Biol. 2:121-128.

36. Küpper H, Benedikty Z, Morina F, Andersen E, Mishra A, Trtilek M (2019) Analysis of OJIP chlorophyll fluoresence kinetics and QA reoxidation kinetics by direct fast imaging. Plant Physiol. 179:369-381.

37. Lešková A, Giehl RFH, Hartmann A, Fargašová A, von Wirén N (2017) Heavy metals induce iron deficiency responses at different hierarchic and regulatory levels. Plant Physiol. 174:1648-1668. https://doi.org/10.1104/pp.16.01916

38. Lešková A, Zvarík M, Araya T, Giehl RFH (2020) Nickel toxicity targets cell wall-related processes and PIN2-mediated auxin transport to inhibit root elongation and gravitropic responses in Arabidopsis. Plant Cell Physiol. 61:519-535. https://doi.org/10.1093/pcp/pcz217

39. Lichtenthaler HK (1987) Chlorophylls and carotenoids: Pigments of photosynthetic biomembranes. Method. Enzymol. 148:350-382. https://doi.org/10.1016/0076-6879(87)48036-1.

40. Mancinelli AL, Yang CPH, Lindquist P, Anderson O, Rabino I (1975) Photocontrol of anthocyanin synthesis: The action of streptomycin on the synthesis of chlorophyll and anthocyanin. Plant Physiol. 55:251-257.

41. Merlot S (2020) Understanding nickel responses in plants: More than just an interaction with iron homeostasis. Plant Cell Physiol. 61:443-444. https://doi.org/10.1093/pcp/pcaa016

42. Mirecki RM, Teramura AH (1984) Effects of ultraviolet-b irradiance on soybean v. The dependence of plant sensitivity on the photosynthetic photon flux density during and after leaf expansion. Plant Physiol. 74:475-480.

43. Mohanty N, Vass I, Demeter S (1989) Impairment of photosystem 2 activity at the level of secondary quinone electron acceptor in chloroplasts treated with cobalt, nickel and zinc ions. Physiol. Plant. 76:386-390. https://doi.org/10.1111/j.1399-3054.1989.tb06208.x

44. Nadgórska-Socha A, Kafel A, Kandziora-Ciupa M, Gospodarek J, Zawisza-Raszka A (2013) Accumulation of heavy metals and antioxidant responses in Vicia faba plants grown on monometallic contaminated soil. Environ. Sci. Pollut Res. 20:1124-1134. https://doi.org/10.1007/s11356-012-1191-7

45. Netty S, Wardiyati T, Maghfoer MD, Handayanto E (2013) Bioaccumulation of nickel by five wild plant species on nickel-contaminated soil. IOSR J. En. 3:01-06.

46. Oukarroum A, Madidi S, Schansker G, Strasser RJ (2007) Probing the responses of barley cultivars (Hordeum vulgare L.) by chlorophyll a fluorescence OLKJIP under drought stress and re-watering. Environ. Exp. Bot. 60:438-446. https://doi.org/10.1016/j.envexpbot.2007.01.002

47. Öz MT, Turan Ö, Kayıhan C, Eyidoğan F, Ekmekçi Y, Yücel M, Öktem HA (2014) Evaluation of photosynthetic performance of wheat cultivars exposed to boron toxicity by the JIP fluorescence test. Photosynthetica. 52:555-563. https://doi.org/10.1007/s11099-014-0065-2

48. Pandey N, Sharma CP (2002) Effect of heavy metals $\mathrm{Co}^{2+}, \mathrm{Ni}^{2+}$ and $\mathrm{Cd}^{2+}$ on growth and metabolism of cabbage. Plant Sci. 163:753-758. https://doi.org/10.1016/S0168-9452(02)00210-8 
49. Parlak KU (2016) Effect of nickel on growth and biochemical characteristics of wheat (Triticum aestivum L.) seedlings. NJAS-Wageningen J. Life Sci. 76:1-5. https://doi.org/10.1016/j.njas.2012.07.001

50. Pourghasemian N, Landberg T, Ehsanzadeh P, Greger M (2019) Different response to Cd stress in domesticated and wild safflower (Carthamus spp.). Ecotox. Environ. Safe. 171:321-328. https://doi.org/10.1016/j.ecoenv.2018.12.052

51. Rao MV, Hale BA, Ormrod DP (1995) Amelioration of ozone-induced oxidative damage in wheat plants grown under high carbon dioxide (role of antioxidant enzymes). Plant Physiol. 109:421-432.

52. Redmann RE, Haraldson J, Gusta LV (1986) Leakage of UV-absorbing substances as a measure of salt injury in leaf tissue of woody species. Physiol. Plant. 67:87-91. https://doi.org/10.1111/j.13993054.1986.tb01267.x

53. Ripoll J, Bertin N, Bidel LPR, Urban L (2016) A user's view of the parameters derived from the induction curves of maximal chlorophyll a fluorescence: Perspectives for analyzing stress. Front. Plant Sci. 7:1-6. https://doi.org/10.3389/fpls.2016.01679.

54. Rizwan M, Imtiaz M, Dai Z et al (2017) Nickel stressed responses of rice in Ni subcellular distribution, antioxidant production, and osmolyte accumulation. Environ. Sci. Pollut. Res. 24:20587-20598. https://doi.org/10.1007/s11356-017-9665-2

55. Roccotiello E, Manfredi A, Drava G et al (2010) Zinc tolerance and accumulation in the ferns Polypodium cambricum L. and Pteris vittata L. Ecotox. Environ. Safe. 73:1264-1271. https://doi.org/10.1016/j.ecoenv.2010.07.019

56. Radotic K, Ducic T, Mutavdzic D (2000) Changes in peroxidase activity and isoenzymes in spruce needles after exposure to different concentrations of cadmium. Environ. Exp. Bot. 44:105-113.

57. Sachan $\mathrm{P}, \mathrm{Lal} N(2017)$ An overview of nickel $\left(\mathrm{Ni}^{2+}\right)$ essentiality, toxicity and tolerance strategies in plants. Asian J Biol. 2:1-15. https://doi.org/10.9734/ajob/2017/33931

58. Salinitro M, van der Ent A, Tognacchini A, Tassoni A (2020) Stress responses and nickel and zinc accumulation in different accessions of Stellaria media (L.) Vill. in response to solution $\mathrm{pH}$ variation in hydroponic culture. Plant Physiol. Biochem. 148:133-141.

https://doi.org/10.1016/j.plaphy.2020.01.012

59. Schaaf G, Honsbein A, Meda AR et al (2006) AtIREG2 encodes a tonoplast transport protein involved in iron-dependent nickel detoxification in Arabidopsis thaliana roots. J. Biol. Chem. 281:2553225540. https://doi.org/10.1074/jbc.M601062200

60. Seregin IV, Kozhevnikova AD (2006) Physiological role of nickel and its toxic effects on higher plants. Russ. J. Plant Physiol. 53:257-277. https://doi.org/10.1134/S1021443706020178

61. Seregin IV, Kozhevnikova AD, Kazyumina EM, Ivanov VB (2003) Nickel toxicity and distribution in maize roots. Russ. J. Plant Physiol. 50:711-717. https://doi.org/10.1023/A:1025660712475

62. Shahzad B, Tanveer M, Rehman A et al (2018) Nickel; whether toxic or essential for plants and environment - A review. Plant Physiol. Biochem. 132:641-651.

https://doi.org/10.1016/j.plaphy.2018.10.014

Page $17 / 25$ 
63. Singh K, Pandey SN (2011) Effect of nickel-stresses on uptake, pigments and antioxidative responses of water lettuce, Pistia stratiotes L. J. Environ. Biol. 32:391-394.

64. Sitko K, Rusinowski S, Kalaji HM, Szopiński M, Małkowski E (2017) Photosynthetic efficiency as bioindicator of environmental pressure in A. halleri. Plant Physiol. 175:290-302. https://doi.org/10.1104/pp.17.00212

65. Stetsenko LA, Pashkovsky PP, Voloshin RA et al (2020) Role of anthocyanin and carotenoids in the adaptation of the photosynthetic apparatus of purple-and green-leaved cultivars of sweet basil (Ocimum basilicum) to high-intensity light. Photosynthetica. 58:890-901. https://doi.org/10.32615/ps.2020.048

66. Stirbet A, Lazár D, Kromdijk J, Govindjee (2018) Chlorophyll a fluorescence induction: Can just a onesecond measurement be used to quantify abiotic stress responses? Photosynthetica. 56:86-104. https://doi.org/10.1007/s11099-018-0770-3

67. Strasser RJ, Srivastava A, Govindjee (1995) Polyphasic chlorophyll a fluorescence transient in plants and cyanobacteria. Photochem. Photobiol. 61:32-42. https://doi.org/10.1111/j.1751-1097.1995.tb09240.x

68. Strasser RJ, Srivastava A, Tsimilli-Michael M (2000) The fluorescence transient as a tool to characterize and screen photosynthetic samples, in: Yunus M., Pathre U., Mohanty P. (ed). Probing Photosynthesis: Mechanisms, Regulation and Adaptation, Taylor \& Francis, London, pp 445-483

69. Strasser RJ, Tsimilli-Michael M, Srivastava A (2004) Analysis of the Chlorophyll a Fluorescence Transient, in: George C. Papageorgiou and Govindjee (ed). Chlorophyll a Fluorescence: A Signature of Photosynthesis. Springer, Netherlands, pp 321-362

70. Strasser RJ, Tsimilli-Michael M, Qiang S, Goltsev V (2010) Simultaneous in vivo recording of prompt and delayed fluorescence and 820-nm reflection changes during drying and after rehydration of the resurrection plant Haberlea rhodopensis. BBA Bioenergetics. 1797:1313-1326. https://doi.org/10.1016/j.bbabio.2010.03.008

71. Syam N, Wardiyati T, Maghfoer MD, Handayanto E, Ibrahim B, Muchdar A (2016) Effect of accumulator plants on growth and nickel accumulation of soybean on metal-contaminated soil. Agric. Sci. Procedia. 9:13-19. https://doi.org/10.1016/j.aaspro.2016.02.109

72. Takarina ND, Pin TG (2017) Bioconcentration factor (BCF) and translocation factor (TF) of heavy metals in mangrove trees of blanakan fish farm. Makara J. Sci. 21:77-81. https://doi.org/10.7454/mss.v21i2.7308

73. Umar M, Uddin Z, Siddiqui ZS (2019) Responses of photosynthetic apparatus in sunflower cultivars to combined drought and salt stress. Photosynthetica. 57:627-639. https://doi.org/10.32615/ps.2019.043

74. Velikova V, Tsonev T, Leoreto F, Centritto M (2011) Changes in photosynthesis, mesophyll conductance to $\mathrm{CO}_{2}$, and isoprenoid emissions in Populus nigra plants exposed to excess nickel. Environ. Pollut. 159:1058-1066. https://doi:10.1016/j.envpol.2010.10.032 
75. Wang SY, Jiao HJ, Faust M (1991) Changes in ascorbate, glutathione, and related enzyme activities during thidiazuron-Induced bud break of apple. Physiol. Plant. 82:231-236.

76. Wang, C, Tian Y, Wang X, Geng J, Jiang J, Yu H, Wang C (2010) Lead-contaminated soil induced oxidative stress, defense response and its indicative biomarkers in roots of Vicia faba seedlings. Ecotoxicology. 19:1130-1139. https://doi.org/10.1007/s10646-010-0496-x

77. Wang Y, Lv N, Mao X Yan Z et al (2018) Cadmium tolerance and accumulation characteristics of wetland emergent plants under hydroponic conditions. R. Soc. Chem. 8:33383-33390. https://doi:10.1039/C8RA04015j

78. Yao X, Liu Q (2007) Changes in photosynthesis and antioxidant defenses of Picea asperata seedlings to enhanced ultraviolet-B and to nitrogen supply. Physiol. Plant. 129:364-374. https://doi.org/10.1111/j.1399-3054.2006.00815.x

79. Yoon J, Cao X, Zhou Q, Ma LQ (2006) Accumulation of $\mathrm{Pb}, \mathrm{Cu}$, and $\mathrm{Zn}$ in native plants growing on a contaminated Florida site. Sci. Total Environ. 368:456-464.

https://doi.org/10.1016/j.scitotenv.2006.01.016

80. Zaid A, Mohammad F, Wani SH, Siddique KMH (2019) Salicylic acid enhances nickel stress tolerance by up-regulating antioxidant defense and glyoxalase systems in mustard plants. Ecotox. Environ. Safe. 180:575-587. https://doi.org/10.1016/j.ecoenv.2019.05.042

\section{Tables}

Due to technical limitations, table 1,2 is only available as a download in the Supplemental Files section.

\section{Figures}



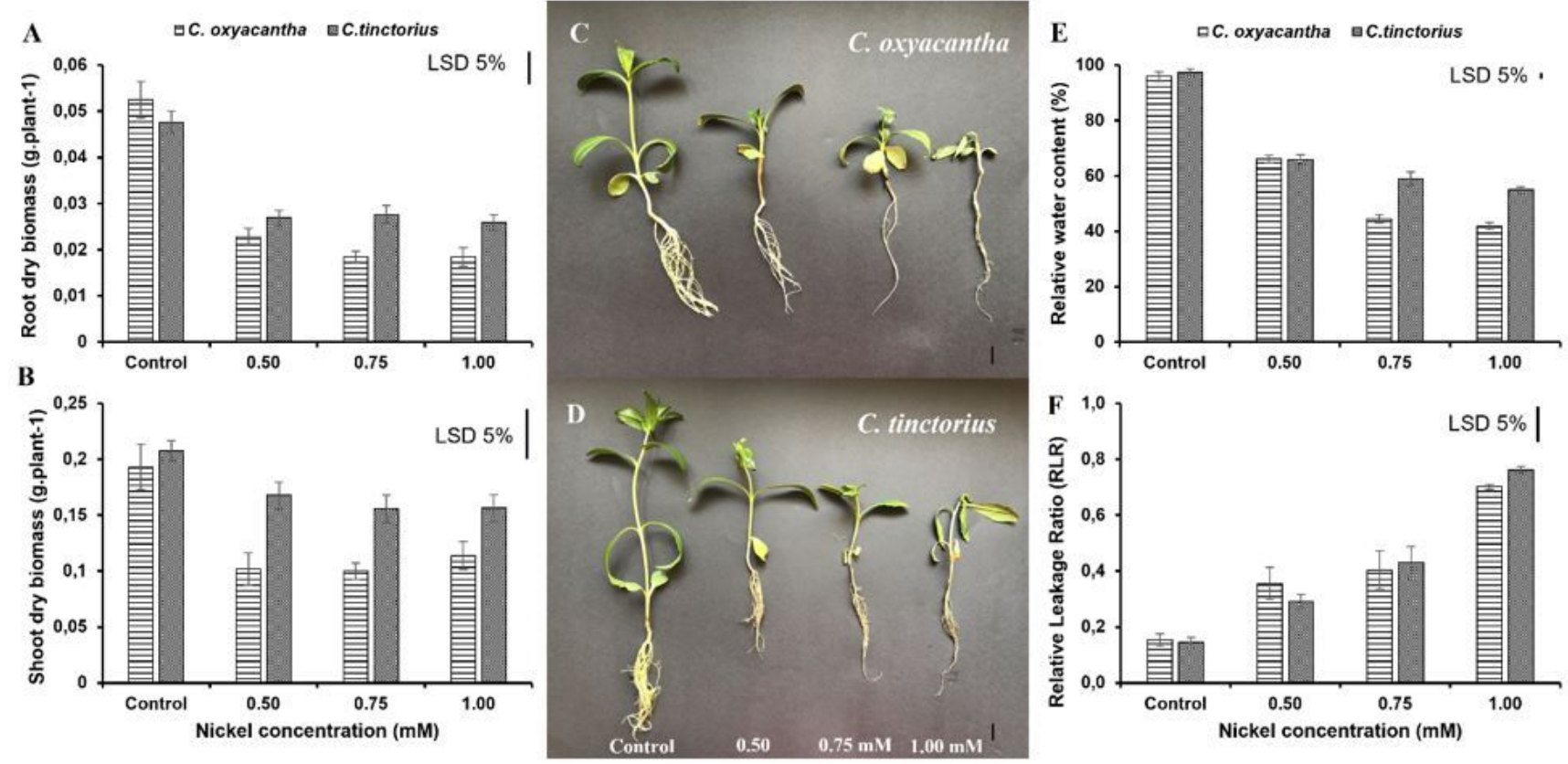

Figure 1

Effects of nickel toxicity on dry biomass of roots $(A)$ and shoot $(B)$, relative water content (E), relative leakage rate $(F)$ of Carthamus oxyacantha and Carthamus tinctorius. The pictures illustrate of $C$. oxyacantha (C) and C. tinctorius (D) exposed to toxic Ni treatments
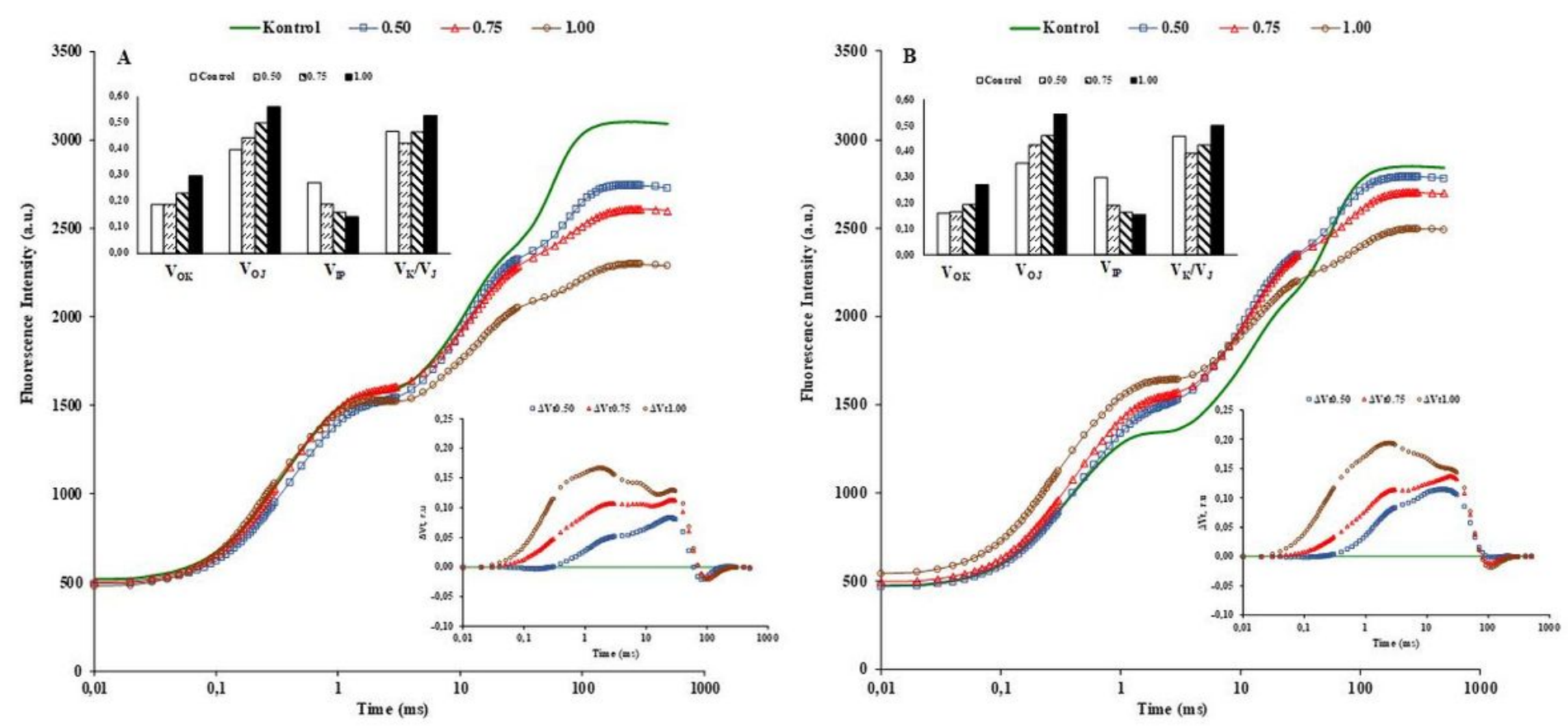

Figure 2 
Changes in the polyphasic chlorophyll a fluorescence kinetics of safflower species exposed to nickel (Ni) toxicity (main plot: A, Carthamus oxyacantha; B, C. tinctorious). The transients are plotted on a logarithmic time scale (0.01-1 s). The upper insert (left) shows the relative fluorescence between the steps (O-K, O-J, I-P) and VK/VJ ratio (a possible indicator of limitation of the oxygen evolving complex, OEC), and the bottom insert shows the relative variable fluorescence $(\Delta \mathrm{Vt})$ between $\mathrm{F} 0$ and $\mathrm{FM}$

$\mathbf{A}$

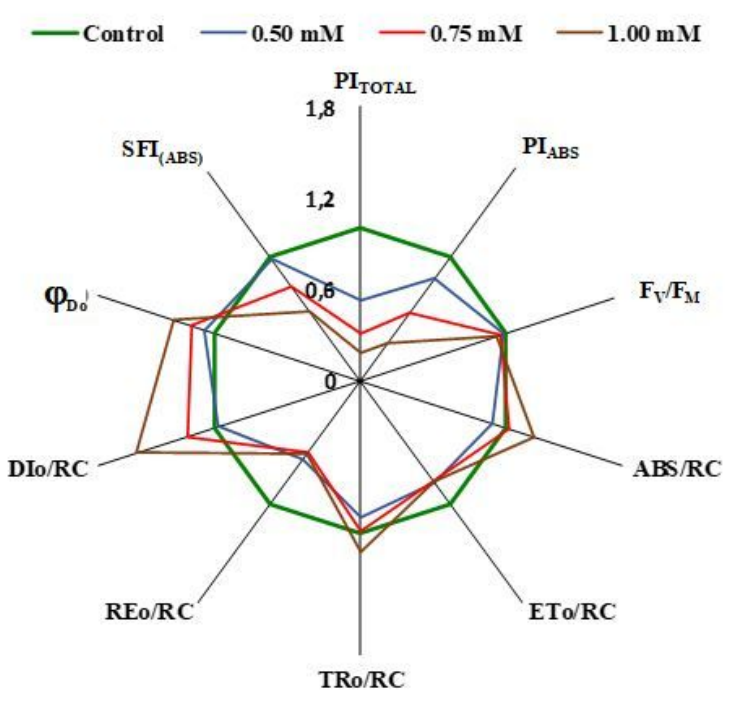

B

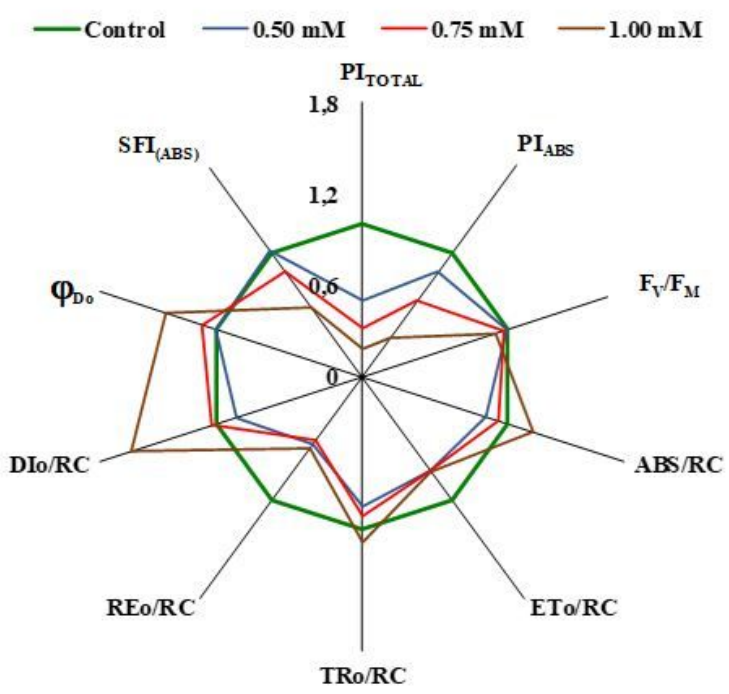

\section{Figure 3}

Radar plot presentation of various JIP-test parameters quantifying the structure and functionality of the photosynthetic apparatus of safflower species (A, Carthamus oxyacantha; B, Crthamus tinctorious) under excessive nickel treatments $(0.50,0.75$ and $1.00 \mathrm{mM} \mathrm{Ni}$ 


\begin{tabular}{ccc}
\hline $\begin{array}{c}\text { Ni Treatment } \\
(\mathrm{mM})\end{array}$ & C. oxyacantha & C. tinctorius \\
\hline
\end{tabular}

\section{Control}
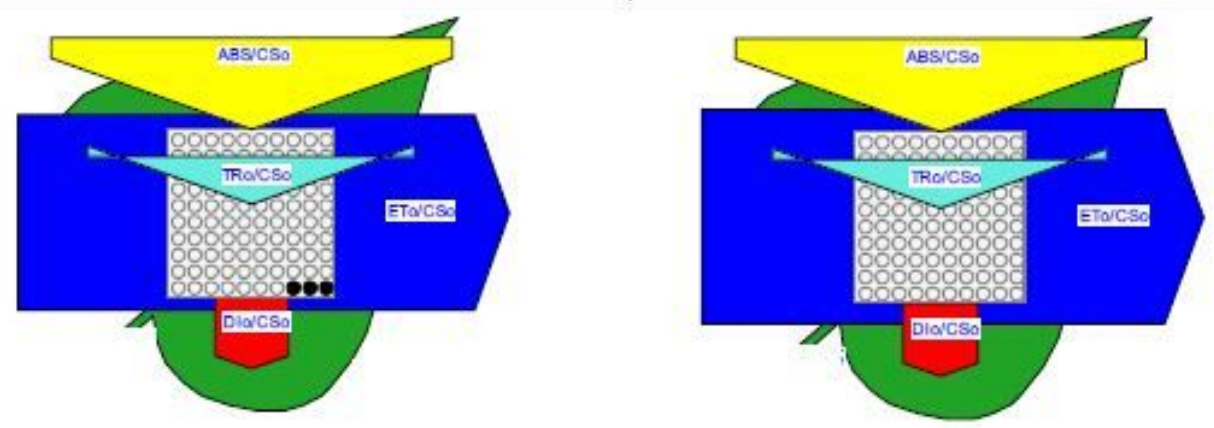

0.50
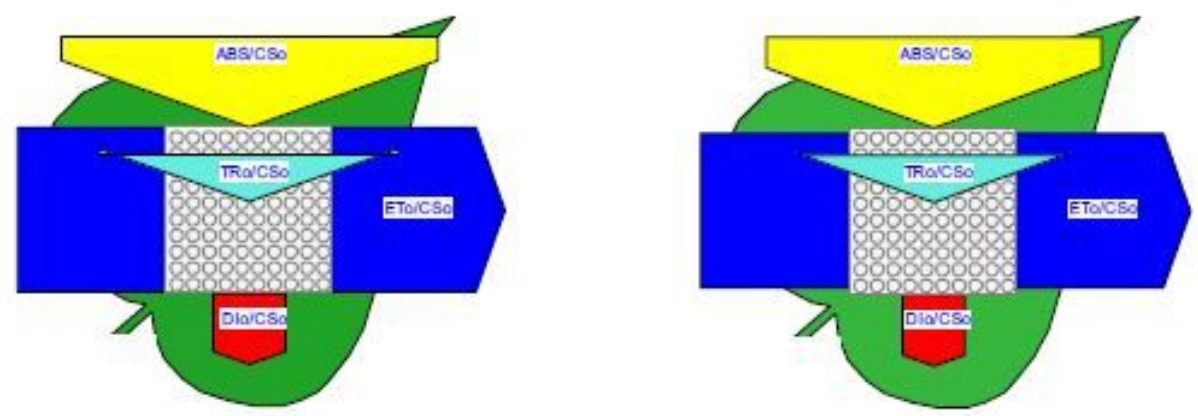

0.75
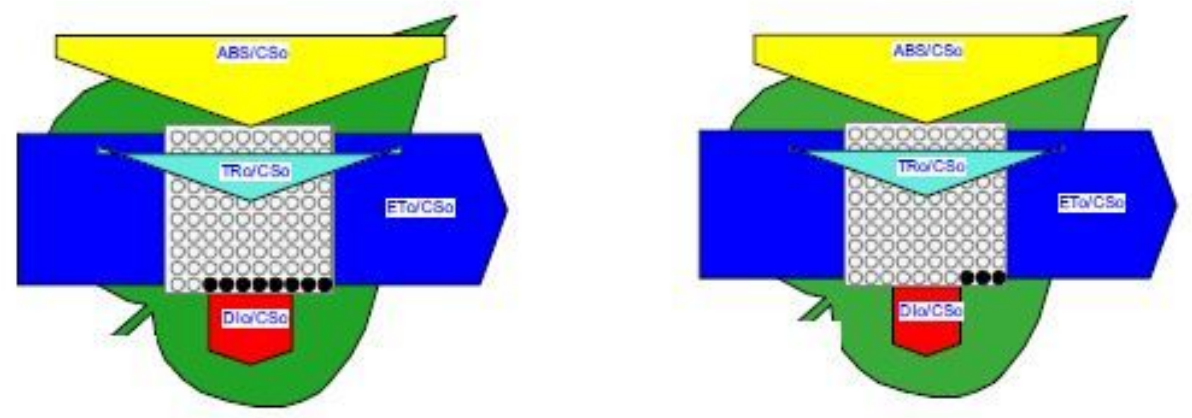

1.00
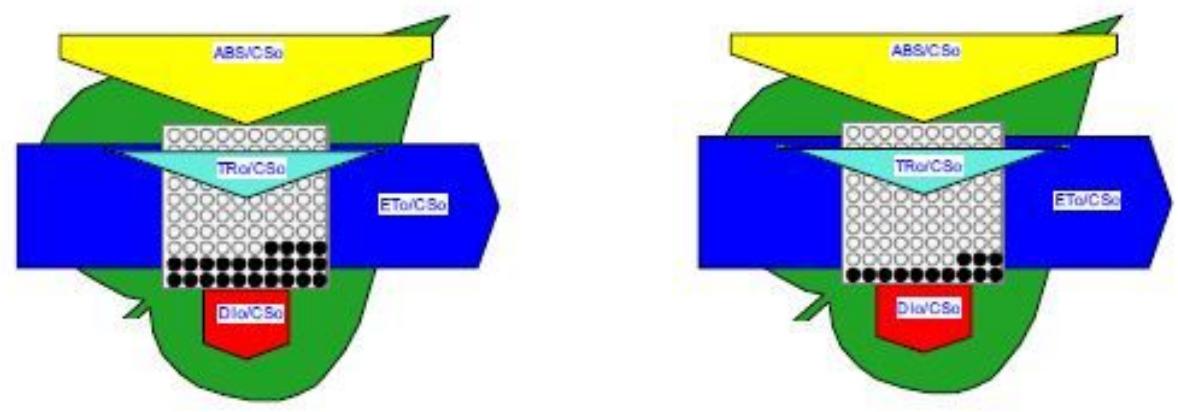

\section{Figure 4}

Energy pipeline leaf models of phenomenological energy fluxes per excited leaf cross section (CSo) of safflower species grown under toxic nickel concentrations. Each relative value is drawn by the width of corresponding arrow, representing the value of a parameter. The value of absorbance (ABS/CSo), trapping flux (TR/CSo), electron transport (ET/CSo) or heat dissipation of excess light (DI/CSo), all expressed per leaf cross section. The black circles represent the fraction of inactive reaction centers. 

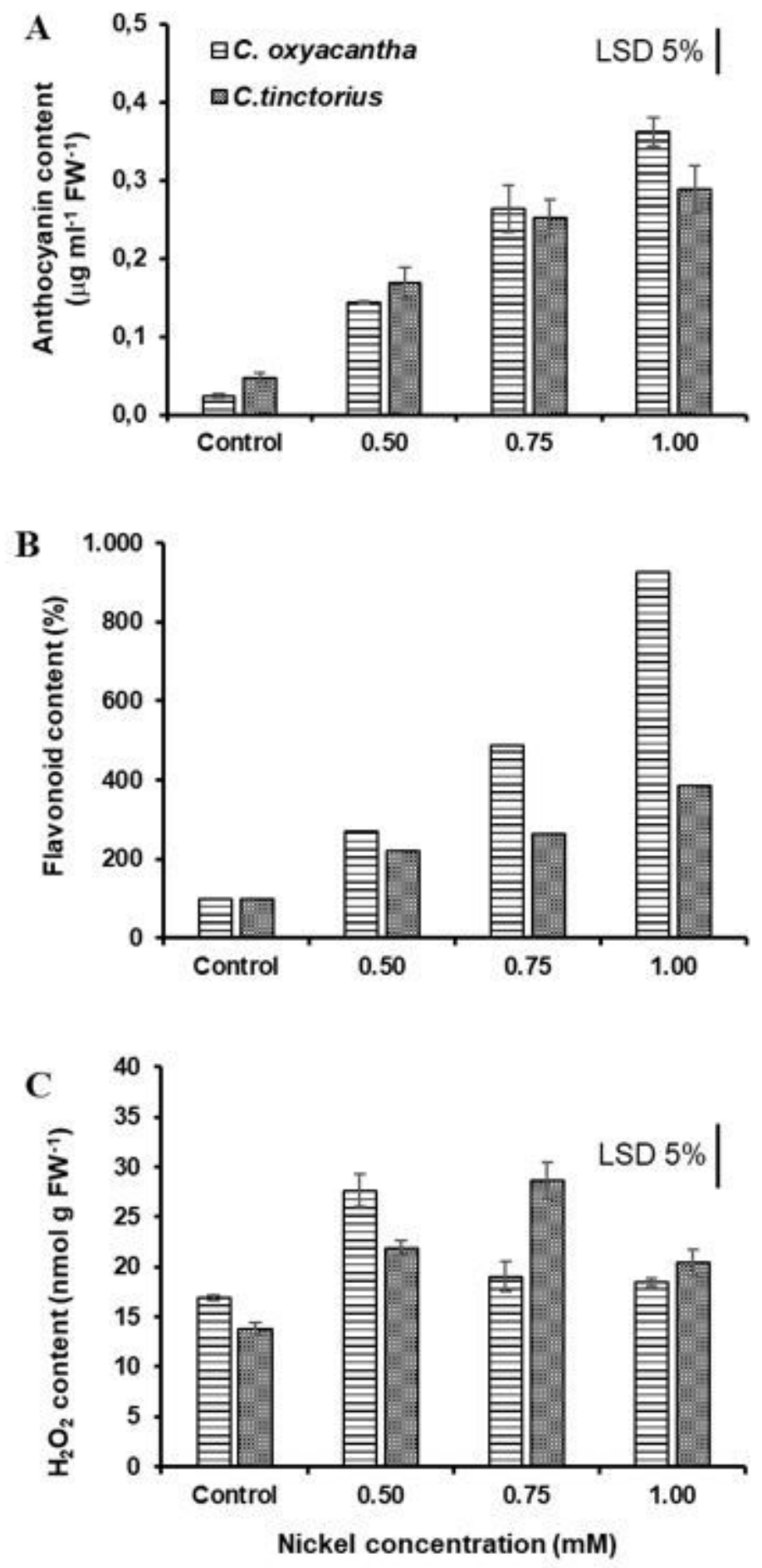

Figure 5

Effects of nickel toxicity on anthocyanin (A), flavonoid (B) and hydrogen peroxide contents of Carthamus species 

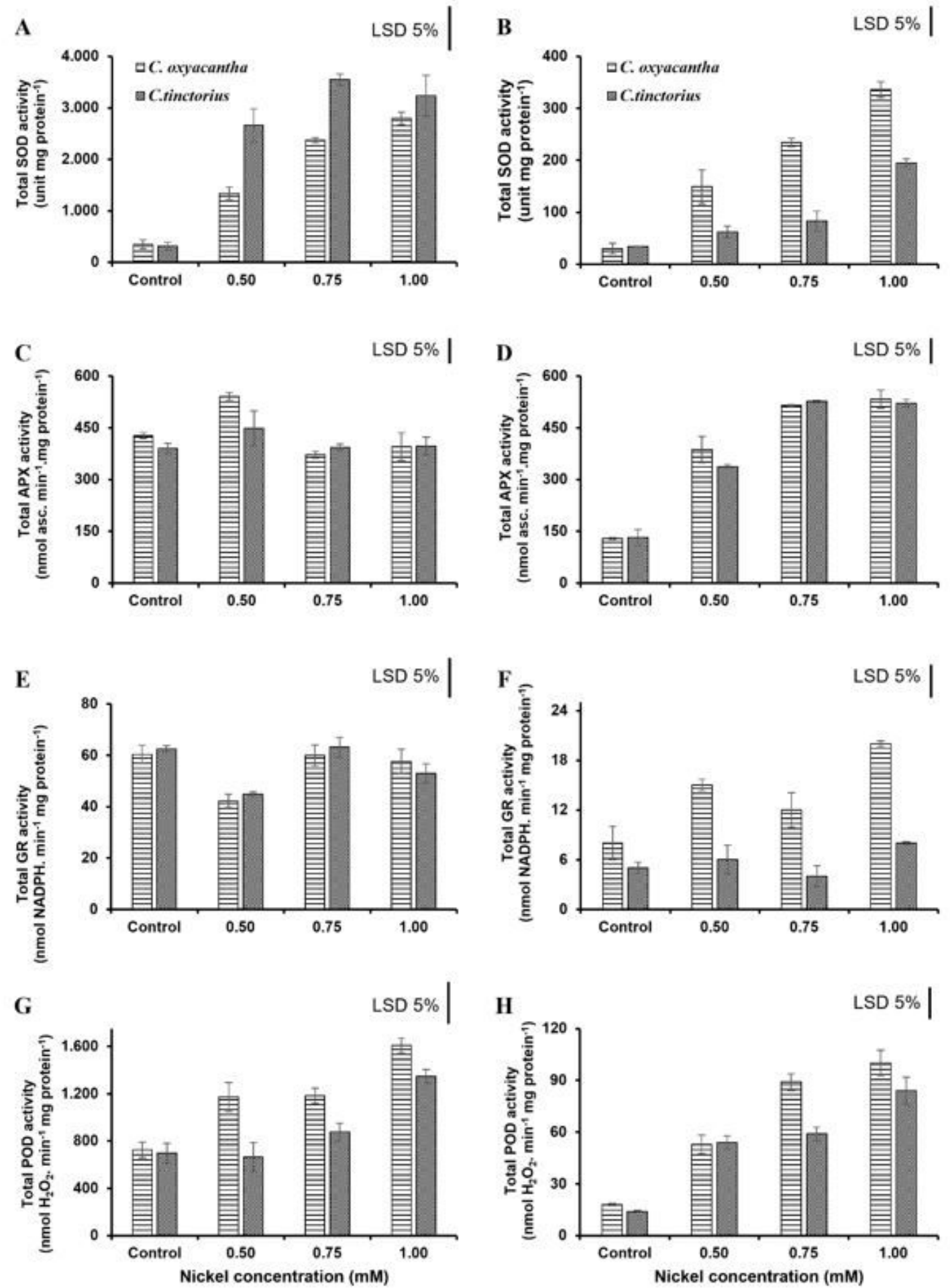

\section{Figure 6}

Changes in antioxidant enzymes of safflower species exposed to toxic Ni levels. Total SOD activities of roots (A) and leaves (B), Total APX activities of roots (C) and leaves (D), Total GR activities of roots (E) and leaves $(F)$, Total POD activities of roots $(G)$ and leaves $(H)$ 
This is a list of supplementary files associated with this preprint. Click to download.

- BaranandEkmekciGraficalAbstract.pdf

- Table1.jpg

- Table2.jpg 